\title{
The geology and hydrocarbon potential of petroliferous basins in China
}

\author{
Of the 9.6 million $\mathrm{km}^{2}$ of land area and 3 million $\mathrm{km}^{2}$ of \\ sea area in China, an area of 5.5 million $\mathrm{km}^{2}$ is covered \\ by explorable sedimentary basins. The in-situ potential \\ resources are estimated at 78 billion tonnes of oil and 33 \\ trillion $\mathrm{m}^{3}$ of natural gas. There have been significant \\ exploration successes in oil and gas exploration in sev- \\ eral different types of basin in formations of wide rang- \\ ing ages. The prospects for further success are very \\ favourable.
}

\section{Introduction}

In China, a total area of 4.2 million $\mathrm{km}^{2}$ is covered by unmetamorphosed sedimentary strata; another 1.3 million $\mathrm{km}^{2}$ of the continental shelf includes basins covered with less than $200 \mathrm{~m}$ of sea water, giving a total of 5.5 million $\mathrm{km}^{2}$ of exploitable sedimentary basins.

By 1950, only three oilfields: Yumen, Yanchang and Dushanzi in north-west China were producing, with a total annual crude output of 0.2 million tonnes $(4000 \mathrm{~b} / \mathrm{d}$ ) only two gasfields, Shiyougou and Shengdengshan in the Sichuan Basin, were producing and the annual natural gas output totaled 10 million $\mathrm{m}^{3}\left(1\right.$ million $\left.\mathrm{ft}^{3} / \mathrm{d}\right)$. In the past four decades, China's oil and gas industry has constantly grown. In the 1950 s, the Yumen oilfield was developed and gas production of the Sichuan Basin increased. Subsequent discoveries include the Karamay giant oilfield and Lenghu oilfields in north-west China. In the 1960 s, the Lower Cretaceous, super-giant Daqing Oilfield in the Songliao Basin was discovered and developed. (the Daqing Oilfield has yielded 55 million tonnes of oil per year, or 1.1 million $\mathrm{b} / \mathrm{d}$ ). In the 1970s, the Bohai Gulf Basin was discovered by the Shengli, Liaohe, Dagang, Huabei and Zhongyuan Petrolcum Administrations. This is a Tertiary rift-depression basin with various types of fault-block oil and gas traps and buried-hill traps. (A total of 153 oilfields have yielded 60 million tonnes of oil per year, or 1.2 million $\mathrm{b} / \mathrm{d})$. In the $1980 \mathrm{~s}$, China cooperated with major foreign oil companies on geophysical exploration and drilling for petroleum in the broad continental shelf of China. In the Bohai Gulf, Beibu Gulf and the Pearl River Mouth Basin, 20 oil and gas fields have been discovered. Ten production oilfields and one gasfield have already been established with an annual production of 6.4 million tonnes of crude oil and 300 million $\mathrm{m}^{3}$ natural gas. More recently, petroleum exploration has been rejuvenated in Western China's five petroliferous basins (the Tarim, Junggar, Turpan, Qaidam and Ordos basins). In the Tarim Basin, the newly discovered oil traps are in Ordovician, Carboniferous, Triassic, Jurassic, Cretaceous and Tertiary strata. The coal-genetic oil traps of the Turpan-Hami Basin are in Jurassic rocks, while in the Central Ordos Basin, large proven gas traps are in Ordovician strata. Meanwhile, the new discoveries in the Erlian Basin, the Kailu Basin and the Bose Basin are significant exploration successes in Inner Mongolia Mesozoic rift basins, south China Tertiary remnant basins and several other basins with small traps and high oil flows.

By 1993, China's crude oil production was 144 million tonnes per year (or 2.8 million b/d). Natural gas production was 15.8 billion $\mathrm{m}^{3}$ per year (or 1.5 billion $\mathrm{ft}^{3} / \mathrm{d}$ ). More than 300 oilfields and 100 gas fields have been developed. Cumulative production of oil was 2.5 billion tonnes and cumulative production of natural gas was 200 billion $\mathrm{m}^{3}$.

The potential resources of oil and gas have been estimated using the methods of basin modelling, pay evaluation and trap evaluation by the Research Institute of Petroleum Exploration and Development with the Petroleum Administration in 1986. The insitu resources were placed at 78 billion tonnes of oil and 33 trillion $\mathrm{m}^{3}$ of natural gas, which is really a large figure. With proven reserves and the present cumulative production of oil and gas, China has undoubtedly a large oil and gas potential.

\section{Geological evolution}

The Chinese craton is composed of the Sino-Korean, Yangtze and Tarim massifs and numerous smaller continental fragments fringed by orogenic belts of different ages. The continent and the continental shelf of China have experienced a complex geological history of plate convergence and divergence from the Proterozoic to the MesoCenozoic (Huang Jiqing et al., 1981. Li Chunyu et al., 1984 and Wang Hongzhen et al., 1985). Tectonic movements (subduction and collision) between the Siberian and Chinese Plates during the Proterozoic and Palaeozoic caused the closure of the Palaeo-sea and accretion of the Chinese craton, forming the E-W collision belts and depressions. Very thick Palaeozoic marine deposits were laid down in intracratonic basins.

Mesozoic and Cenozoic tectonism mainly caused by the retreat of Tethys and collision between India and Eurasia exerted strong compression on western China. The $\mathrm{E}-\mathrm{W}$-trending mountain chains appeared as a major geologic feature, persisting to the present day. Pacific subduction became even more intense after the Yanshanian Orogeny and the whole of east and central China was affected by Pacific tectonism. New NNE-trending mountain chains inherited the previously existing $\mathrm{E}-\mathrm{W}$ geological characteristics, forming a series of intraplate rifi-depression basins in the eastern part of China (Zhu Xia, 1979; Li Desheng, 1980; Tong Chongguang, 1980; Hu Jianyi et al., 1982). The Chinese craton was pulled apart, and there was a rise of the upper mantle. Eastern China was entirely dominated by rifting tectonism (Walcott, 1970; Ziegler, 1975; Murrell, 1976; Li Desheng, 1980, 1982; Ma Xingyuan, 1986). The Chinese craton and the sedimentary basins lying on it in which thick lacustrine sediments are deposited owe much of their evolution and present day configuration to this tectonic history.

\section{Geological characteristics of oil and gas basins in China}

\section{Non-marine facies oil generation}

As early as the 1940s, the Chinese geologists Pan (1941) and Sun (1943) put forward the theory that petroleum could be generated in non-marine sediments. For example, the source rocks of Yanchang oilfield of Ordos Basin and Yumen oilfield of Jiuquan Basin are non- 


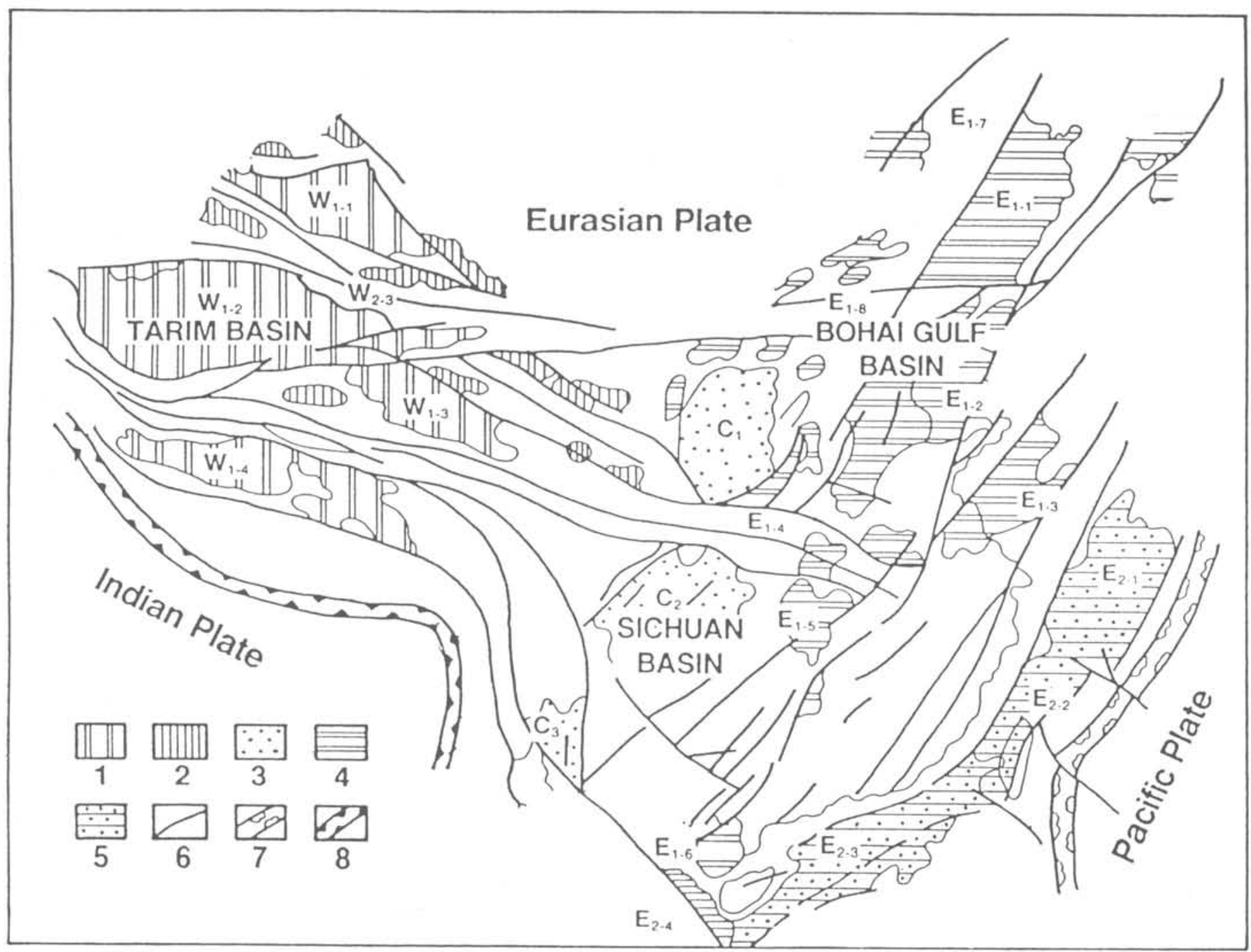

Figure I Tectonic types of oil and gas basin in East Asia (after Li, 1985). I Western large-scale composite basin;

\section{Western mountain front and} intermontane basin; 3 Central intraplate subsidence basin;

marine. In the 1950s, oil fields were discovered successively in the Junggar Basin, the Qaidam Basin and the Central Sichuan Basin in non-marine source rocks of Mesozoic and Cenozoic age. Many Chinese petroleum geologists and geochemists have described oil generation in rocks of non-marine facies, and have discussed the source materials, environment and conversion conditions. In the 1960s, the discovery and development of the super-giant Daqing Oilfield in the Songliao Basin has proved that petroleum can accumulate in continental facies rocks, and that oilfields in non-marine sediments may be very prolific and reach super-giant size. The Daqing Oilfield has yielded a peak production of 50 million tonnes of oil per year (1 million b/d) for 19 years. By 1994, the cumulative oil productions of Daqing was 1.3 billion tonnes (or 91 billion barrels).

Following the large-scale regression, which occurred in the Late Permian (north China) or Middle Triassic (south China), lacustrine deposits of Mesozoic and Cenozoic age were extensively laid down. The continental rock series were developed in various basin centres during periods of rifting and depression. The source rocks are of different ages and are widespread in Late Permian, Late Triassis, Early-Middle Jurassic, Early Cretaceous, Palaeogene and Neogene sediments. Those of Early Cretaceous and Palaeogene age are the most important.

Continental oil is generated in lacustrine deposits rich in terrigenous organic matter. In particular high carbon-number mole-

\section{6 major fault zones; 7 West Pacific subduction zone; 8 Yarlung Zangbo river collision belt.}

cules originating from wood-wax (phyto-wax) constitute the basis for continental crude oil with high wax and low sulphur contents.

\section{Tectonic classification of oil and gas basins in China}

Many classifications have been proposed for Chinese oil and gas basins, such as Huang Jiqing, 1957; Chen Guoda, 1965; Zhu Xia, 1980; Guan Shicong et al., 1981; Li Desheng, 1982; Guo Lingzhi et al., 1983 and Bally, 1986. A new classification is based on plate tectonics theory, especially since the Meso-Cenozoic, combined with data from geophysical surveys and drilling. Three basic types of oil and gas basins in China are proposed (Figure 1):

- The basins in eastern China can be classified as tension types (some of them are of the tensile shearing type). Bouguer gravity anomalies in the east range from 0 to $-50 \mathrm{mGal}$, the crustal thickness is $25-35 \mathrm{~km}$, and the geothermal gradient is $3.5-4.5^{\circ} \mathrm{C} / 100 \mathrm{~m}$. Examples include the Songliao Basin, the Bohai Gulf Basin, the Subei-South Yellow Sea Basin, the Nanyang-Biyang Basins, the Jianghan Basin, the Beibu Gulf Basin, the Yinggenhai Basin and Zhujiang River Mouth Basin.

- The basins in central China can be classified as transitional types. These basins have been affected by both the TransEurasian Tethys tectonism and the circum-Pacific tectonism, with dual extensional and compressional-shearing mecha- 
nisms. Basins in this category include the Ordos Basin, the Sichuan Basin and the Chuxiong Basin. Bouguer gravity anomalies in the central part of China range from - 100 to -250 mGal. the crustal thickness is $35-45 \mathrm{~km}$, and the geothermal gradient 2.5-3.0 $\mathrm{C} / 100 \mathrm{~m}$.

- Basins in western China are compressional types (some of them of compressional-shearing type). These basims have been formed by the northward-impacting Indian Plate. Examples include the Jarge-scale composite basins, such as the Junggar and Tarim basins; piedmont basins such as the Osu Basin.

Kuqa Basin. Yecheng Basin, Jiuquan Basin and Minle Basin; and intermontane basins like the Turpan Basin. Bouguer gravity anomalies in the west part of China range from - 100 to $-575 \mathrm{mGial}$, crustal thickness is $45 \ldots 70 \mathrm{~km}$, and the geothermal gradient is $2.02 .50^{\circ} \mathrm{C} / 100 \mathrm{~m}$.

During the palaeo-plate tectonic stages, there were widespread marine transgressions on to the China Craton. Thick carbonate sediments and marine origin source rocks are distributed in some Palacozoic petriliterous basins in the plattorm regions.

\section{Mesozoic and Cenozoic lacustrine facies models}

More than $90 \%$ of China's crude oil is produced from Meso-Cenozoic terrestrial reservoir formations and petrophysical properties are important in the evaluation oil and gas pools within them. Ye Lianjun. Sun Shu, Wu Chongyun (1986) and Qiu Yinan et al.. (1980) have established two models (depression and rift) for Meso-Cenozoic lacustrine facies using drilling records, well logging data and 3-D seismic data.

\section{Composite megastructural oil and gas belts}

The Bohai Gulf Basin was subjected to strongly dilferential block faulting in the Tertiary. A series of normal faults developed and abundant oil and gas reserves have been trapped in complex geological structures. Chinese petroleum geologists and geophysicists have proposed, after long study, that different pay-horizons and different trap-types may evolve in similar ways and interact with each other, in megastructural oil and gas belts. This theory has led 10 a better understanding of oil and gas generation, and of the "rules' of hydrocarbon distribution and abundance in the Bohai Gull Basin. There are six conceptual models for megastructural oil and gas belts. distributed around the source area centres:

- the central anticline composite megastructural belt;

- the low buried-hill composite megastructural belt;

- the highly uplifted composite megastructural belt;

- the synsedimentary fault and roll-over anticline megastructural belt:

- the structural slope composite megastructural belt, and

- the basin trough lithological megastructural belt.

Applying this theory, in the Bohai Gulf Basin, the Shengli, Liache. Dagang, Zhongyuan, Huabei Petroleum Administrations and the Bohai Oil Corporation improved development technology, and 153 oil and gas fields (including 12 giant oilfields) have been exploited. Since 1986. crude oil production in the Bohai Basin has reached 60 million tonnes per pear. By the end of 1994 , cumulative oil production was 1.05 billion tonnes (or 7.35 billion barrels). The Bohai Gulf Basin has become another important oil and gas province of China.

\section{Buried-hill oil and gas traps}

The continent and the continental shelf of China have had a complex geological history during which uplifted parts of the basement have undergone weathering and karstification over long geological periods. Oil and gas from later overlying formations, have migrated into the basement rocks and held in what have been termed buried-hill traps (Yan Dunshi, Wang Shangwen, Tang Zhi, 1980).

The Yaerxia oilfield, discovered in 1959 in the Jiuquan Basin. NW China, was the first recognised huried-hill oil trap. The Lower
Cretaceous greyish black shales are considered to be the source bed here, and the Silurian metamorphic series below a Cretaceous uncomformity forms the buried-hill trap. Its cumulative oil production was 6000000 tonnes.

In July 1975, the Renqiu oilfield in Hebei Province was discovered. This oilficld lies in the Jizhong depression of the Bohai Gulf Basin. The discovery well penetrated a Proterozoic Wumishan dolomite reservoir formation and the tested flow rate of oil was $1000-3000$ tonnes/d. During 1977-1981, the annual oil production was maintained at more than 10 million tonnes. Cumulative oil production up to 1994, was 120 million tonnes (or 840 million barrels). Chinese geologists have proposed that the oil comes from the Oligocene Shahejic formation in the Yaloyang sag. Since the discovery of the Renquiu Oiltield. exploration has been undertaken in similar basins, such as the Jizhong, Jivang. Liaohe, Huanghua and Bozhong depressions. To date, more than 40 tilted fault block-buried hill oil traps have been discovered. Among them, the Dongshenpo-Jinganpo buried-hill trap is another giant. The reservoir rocks are Archaen gnciss plus Middle and Late Proterozoic carbonates.

\section{Coal-genetic hydrocarbons}

Coal measure strata are widespread in China, and include Early Carboniferous, Permo-Carboniferous, Late Permian, Early Triassic, Iate Triassic, Early Middle Jurassic, Late Jurassic and Tertiary series, distributed in different giant sedimentary basins. The high humic organic matter (type III) in these occurrences has been divided by (hinese natural gas geologists and geochemists into two subtypes. Type $\mathrm{II}_{1}$ (containing sapropel) is a kerogen with liquid hydrocarbon-generating potential, while type $\mathrm{III}_{2}$ kerogen is a typical gass-generating source material ( Bao Ci et al., 1988; Huang Difan et al., 1991; Dai Jinxing et al., 1992). It is interesting to note that the coal-genetic hydrocarbons either accumulated in the coal series themselves, or migrated into reservoir formations above or below.

By the use of multidisciplinary techniques including gas geochemistry. many coal-genctic gasfields have been proved in recent years, such as the Triassic Xiujiahe Formation Zhongba Gasfield: the Triassic Xlangxi Formalion Suinan Gasfield in Sichuan Province: the Palacogene Sha-4 member Wenliu Gasfield in Henan Province; the Permo-Carboniferous Suqiao Gastield in Hebei Province; the Oligocene Y 13-1 Gatsfield in offshore Yinggehai Basin and the offshore Miocene and Oligocene Pinghu Gasfield in the East China Sea Basin. Recently, the Jinghian-Hengshan Gasfield in the central part of the Ordos Basin was discovered. Its reservoir rocks are Lower Ordovician Majiakou karstic dofomites which underlie, with unconformity, source rocks in the Middle Carboniferous coal series. The structure of the gasficld is a gentle west-dipping monocline. Eastwards, the Majiakou dolomites display an up-dip facies change to salt and gypsum which constitute the cap rocks.

Coal-genetic oilfields have been discovered in Middle and Lower Jurassic strata - in the Qiketai Formation. Sanjianfang Formation, Xishanyao Formation $\left(J_{2}\right)$ and Badawan Formation $\left(J_{1}\right)$ in the Turpan and Junggar basins, north-west China. The Shanshan Oilfield was discovered in 1989 and the Qiuling Oilfield in 1990 in a Ushaped anticlinal belt of the Turpan Basin. In the eastern Junggar Basin desert area, the new Cainan Oilfield was discovered in 1991. In 1993, the annual production of these three oilfields was 2.6 million tonnes $(52000 \mathrm{~b} / \mathrm{d})$. The oils are typical non-marine coalderived light oils with low specific gravity $(0.79-0.82)$. low viscosity, low sulphur, medium wax content and rich in wet gas.

\section{Exploration of Palaeozoic marine sediments}

The Sichuan Basin, eovering an area of $230000 \mathrm{~km}^{2}$, lies in the central part of the Yangtze Craton. The gas pay horizons including Sinian, Carboniferous. Permian and Triassic carbonates are of marine facies. The Sichuan Basin is China's most important gas producer. delivering $44 \%$ of the annual natural gas production. The cumulative production is 140 billion $\mathrm{m}^{3}$. 
The Tarim Basin is one of the largest and least explored inland basins in China. with an area of $560000 \mathrm{~km}^{2}$. Multiple source rocks for hydrocarbon generation occur in thick Palaeozoic marine platform deposits and in Meso-Cenozoic terrestrial deposits. The Tarim basin has been an object of special attention by seismic exploration and deep drilling since 1983-1984, leading to the discoveries of eight oil and gas fields and 23 structures with oil or gas shows in Tabei, Lunnan, Tazhong and South-west Slope. The reservoir formations are Ordovician platform dolomites; Carboniferous transitional facies carbonates and clastics; and Triassic, Jurassic, Cretaceous and Tertiary terrestrial clastics. Four oilfields. Lumnan, Sangtamu, Jiefangjudong and Donghetang, have been developed. In 1994, the annual crude oil production was 2 million tonnes which may increase to 5 million tonnes in 1996 , when the Tazhong number four Oiltield which lies in the central part of Taklimakan Desert comes on-stream. In 1993, the south-east part of the Tarim Basin, with an area of $7.3000 \mathrm{~km}^{2}$ (divided into five blecks) was open to foreign oil companies bidding for exploration contracts. The total oil and gas potential resources in the Tarim Basin have been estimated at 19.1 billion tonnes, made up of 10.7 billion tomes of oil and 8.4 trillion $\mathrm{m}^{3}$ of natural gas. The potential, in-situ oil and gas resources of marine Palaeoroic strata have been estimated to be 14 billion tons. about $73 \%$ of the total resources. The non-marine Meso-Cenozoic strata has been estimated to hold in situ, 5.1 billion 1ons, about $27 \%$ of the utal resources. Thus, the Tarim basin is a very important frontier arca for petroleum exploration in Palaeozoic marine sedimentary rocks of China.

The Ordos (Shanxi-Cansu-Ningxia) Basin, $320\left(000 \mathrm{~km}^{2}\right.$ in area is located on the west part of Sino-Korean massif. The Yanchang Oiltield was discovered as early as 1907. Reservoir rocks at Yanchang and in the Changing oillield are terrestrial facies Upper
Triassic Yanchang sandstones and Lower Jurassic Yanan sandstones. Annual production of the Yanchang and Changeing oilticlds was 6 million tonnes in 1994 and cumulative oil production was 30 million tonnes. In 1986, the discovery of the Tianchi gas structure in the western part of the basin and, in 1989, of the Jingbian gastield in the central part of basin were breakthroughs in deep gas exploration. The gas reservoir rocks are Lower Ordovician Majiakou dolomites. This discovery has established the presence of new frontier areas for exploration in Palaeozoic marine facies in the Ordos Basin. Now, a $2000 \mathrm{~km}^{2}$ area of gas has been established, with proven reserves of 200 billion $\mathrm{m}^{3}$. The Ordos Basin will become the next important gals province in central China.

The successes in the Sichuan, Ordos and Tarim basins give hope of discoverics being made elsewhere. For example. thick Palacozoic marine sediments are widespread in southern China. but little work has been done on exploring them.

\section{Conclusion}

Practical and theoretical research work has demonstrated that over China's vast onshore and of fshore areas, geological conditions are favourable for the generation and accumulation of oil and gas and there are many new frontier areas for exploration. In the future. through the in-depth study of petroleum geology. and using new techniques and methods in exploration and exploitation, more oil and gas reserves will be found and developed both on- and of fishore. including new giant oil and gas lields. Chinese geoscientists will do their best to further develop the petroleum industry and the science of petroleum geology in China.

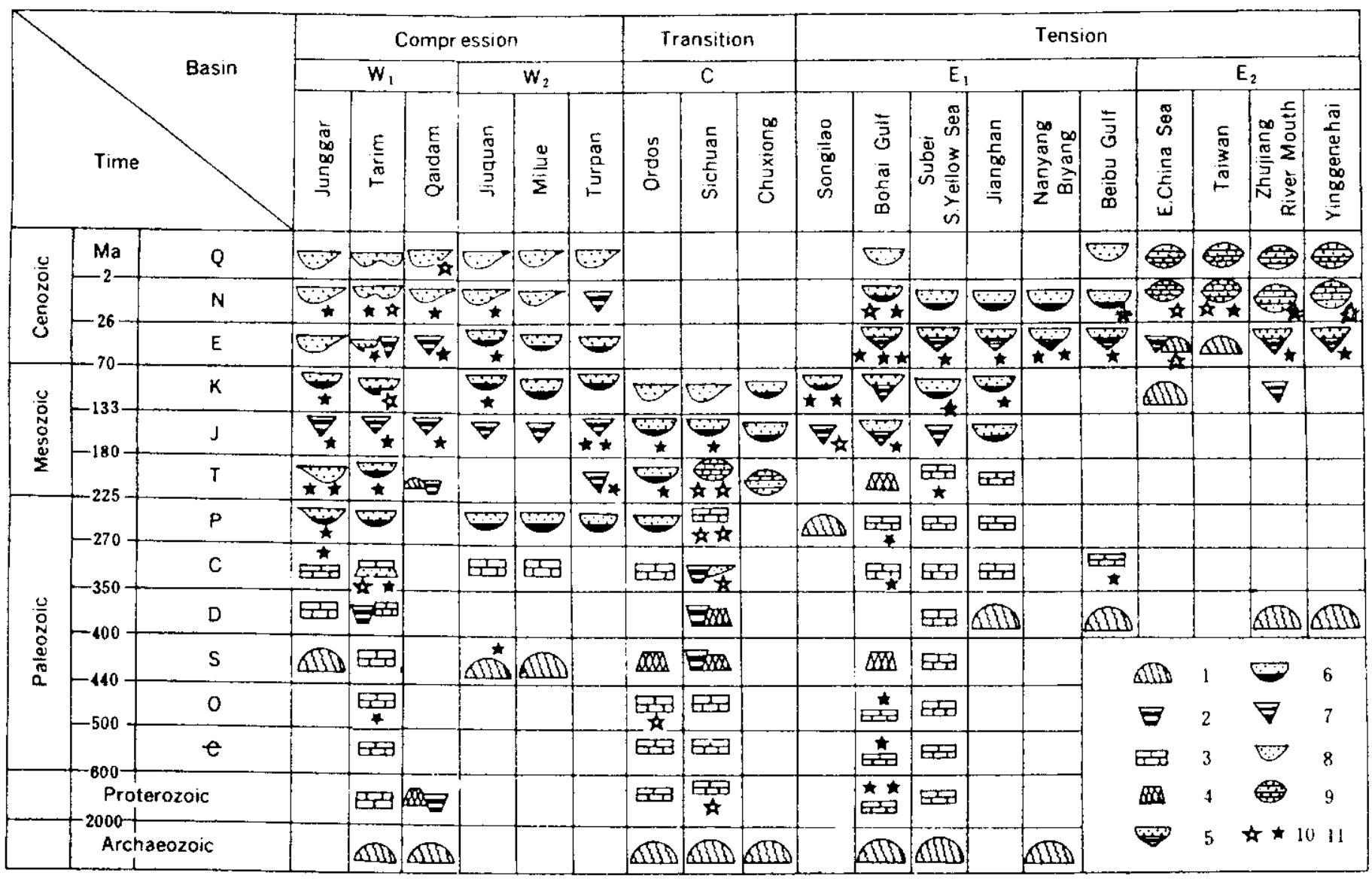

Figure 2 Polycyclic oil and gas basins in China

1 metamorphic basement; 2 trough; 3 platform; 4 uplift; 5 composite basin; 6 rift-subsidence basin; 7 intermontane basin;

8 mountain front basin; 9 continental crust margin basin; $10 \& 11$ oil and gas borizons. 


\section{References}

Bally A W et al., 1986, Notes on sedimentary basins in China: US Geological Survey, open-file report, 86-327, 108pp.

Bao Ci, ed., 1988, Natural gas geology: Science Press, Beijing, China.

Chang Wenyou, Ye Hong, and Zhong Jiayou, 1978, On fault blocks and plates: Scientia Sinica, no. 2.

Chen Guoda, 1965. Geodepression (Diwa) - a new activated post-platform regions, in The geo-tectonics of China: Science Press, Beijing, China pp. $1-52$.

Dai Jinxing, Pei Xigu, Qi Houfa, eds., 1992, Natural gas geology in China: China Petroleum Press, Beijing, China.

Department 7, Institute of Geology, Academia Sinica, 1978, The deltaic systems of Lower Oligocene of Liaohe Western Depression: Petroleum Exploration and Development, no. 6.

Fu Jiamo et al., 1978, On some problems in research of organic geochemistry of petroleum: Geology-Geochemistry, pp.18-29.

Guan Shicong, et al., 1980, Geology history of late Proterozoic to Triassic in China and associated hydrocarbons, in Mason J F, ed., Petroleum Geology in China: Pennwell Books, pp.142-153.

Guo Lingzhi, Shi Yangshen and Ma Ruishi, 1983, On the formation and evolution of the Mesozoic-Cenozoic active continental margin and island arc tectonics of the western Pacific Ocean: Acta Geologica Sinica, v. 57, no. 2. pp.11-21.

Hu Jianyi et al., 1982 Tectonic framework and oil possibilities of Mesozoic rocks in the Bohai Bay and its neighbourhood: Acta Petrolei Sinica, v. 3, no. 2. pp. 1-8.

Huang Di fan and $\mathrm{Li}$ Jinchao, eds., 1982, Oil and gas generation of continental facies in China: Petroleum Industry Press, Beijing, China.

Huang Difan, Zhang Dajiang, Li Jingchao, and Huang Xiaoming, 1991, Hydrocarbon genesis of Jurassic coal measures in the Turpan Basin, China: Organic Geochemistry v. 17, no, 6, pp.827-837.

Huang Jiqing, Ren Jishun et al., 1981, The geotectonic evolution of China: Science Press, Beijing, China.

Li Chunyu et al., 1984, Tectonic evolution of Asia: Bulletin of the Chinese Academy of Geological Sciences, no. 10.

Li Desheng, 1991, Tectonic types of oil and gas basins in China: China Petroleum Press, Beijing, China.

Liu Grangding ed., 1992, Map series of geophysics of China Seas and adjacent regions (1:5000 000): Geological Publishing House, Beijing, China.

Ma Xingyuan, ed., 1987, Geodynamic map of crust of China and adjacent sea regions (1:4 000 000): Geological Publishing House, Beijing, China.

Murrell S A F, 1986, Tectonophysics. v. 36, pp.5-24.

Pan Chung-Hsiang, 1941, Non-marine origin of petroleum in North Shensi and the Cretaceous of Szechuan, China.

Qiu Yinan, Wang Hengjian and Xu Shiche, 1980, Characteristics of oilwater movement in fluvial-deltaic sandbodies deposited in continental lake basins: Acta Petrolei Sinica, Special Issue, pp.73-94.

Sun Jianchu, 1943, Outline of a national programme for petroleum development in China: Notes of Geology, pp.11-18.

Tian Zaiyi ed., 1959, Proceedings of oil and gas generation of continental facies in China and petroleum exploration: Petroleum Industry Press, Beijing, China.

Tong Chongguang, 1980, Geological characteristics of the rift valley systems in the Eastern China: Acta Petrolei Sinica, v. 1, no. 3.pp.19-26.

Walcott R I, 1970, Journal of Geophysical Research, v. 75, pp 3941-3954.

Wang Hongzhen et al., 1985, Atlas of the paleogeography of China: Cartographic Publishing House, Beijing, China.
Wu Chongyun, 1986, Sand bodies in lake basin: Acta Sedim. Sinica, v. 4, no. 4. pp. $1-7$.

Yan Dunshi, Wang Shangwen, and Tang Zhi, 1980, Block faulting and formation of oil and gas fields associated with buried hill in Bohai Bay Basin: Acta Petrolei Sinica, v. 1, no. 2, pp.1-10.

Zhang Kai, Luo Zhili, and Zhang Qing, 1980, Classification of basins and potential hydrocarbons resources in China: Acta Petrolei Sinica, v. 1, no. 4, pp. 1-8.

Ziegler P A, 1975. Petroleum geology and geology of the North Sea and northeast Atlantic continental margin: Bergen Conference Proceedings. Universitesforlaget, Trondheim, Norway, pp.1-27.

Zhu Xia, 1978, On the basic geologic problems concerning the Meso-Cenozoic continental facies oil and gas basins in China: Petroleum Geology Practice, Monograph, Wuxi, Jiangsu, China.

Desheng $\mathrm{L}$, graduated in geology from the China National Central University in 1945. He worked at several oil/gas fields from 1945 to 1977 and, since 1978, he has been Chief Geologist and Professor at the Research Institute of Petroleum Exploration and Development in Beijing. He became an Academician of the Chinese Academy of Sciences in 1991. His research has included petroleum geology, tectonic structure, basin analysis and reservoir characterization studies. In 1994, he was given an AAPG Distinguished Achievement Award (International).

Guangding Liu, graduated in physics from Beijing University in 1952. He was the head of the first Marine Geophysical Brigade in China and has held several senior positions in geophysics, petroleum geology and marine geology in the Ministry of Geology and Mineral Resources. He was Director of the Institute of Geophysics, Chinese Academy of Sciences from 1989 to 1993. Now, he is the president of the China Geophysics Society and president of the Chinese Committee of IUGG. He became an Academician in 1980 and has won a series of national prizes.
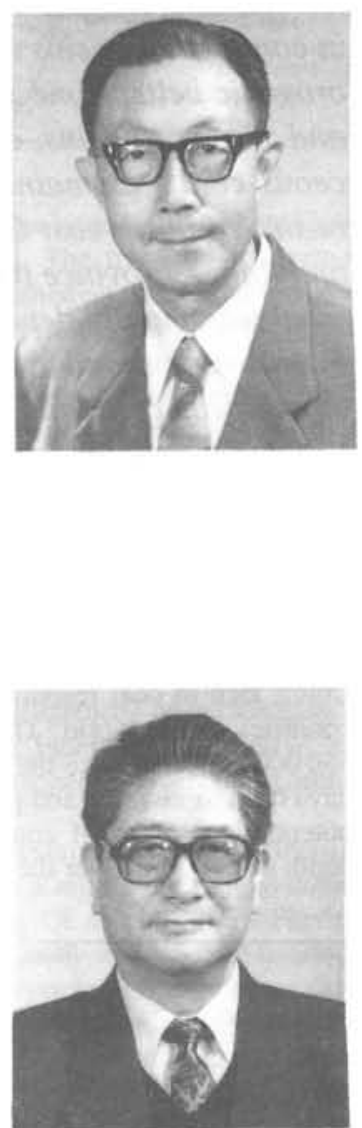